\title{
Historical Thinking in Revolutionary New Jersey: \\ Ancient and Medieval History at Liberty Hall
}

\section{By Christopher M. Bellitto}

\section{DOI: http://dx.doi.org/10.14713/njs.v2i1.26}

By exploring the newly-accessible Liberty Hall Archives affiliated with Kean University in Union NJ, this micro-study of the historical references in the writings of John Kean, first cashier of the Bank of the United States, and William Livingston, New Jersey's first governor, reveals how two colonial and revolutionary gentlemen-one tutored at home in South Carolina and the other trained at Yale with a law practice in New York City-employed historical analogies in their pursuit of revolution and government-building. Specifically, how both the Kean paterfamilias and the builder of Liberty Hall used allusions to Greco-Roman history (and, in Kean's case, to medieval Britain) provides insight into the manner that one time period of history adopted and adapted prior periods. Such a study reveals how Kean and Livingston, with diverse backgrounds and from different parts of early America, used history as they made their own.

"Where are now her Scipios, and Tullys, her Brutuses, and her Catos, with other Names of equal Lustre, who plann'd her Laws, and fought her Battles, during her Freedom and Independence?" So wrote William Livingston rhetorically in 1752 , looking at the contemporary Papal States as a lamentable monarchy and recalling with sadness the great Roman republic that had once stood there. ${ }^{1}$ Livingston reached for a standard topos in early American literature: the use of a reference to antiquity, in this case Republican Rome, to compare a currently unfavorable state of events with a glorious past. Long research has indicated the desire of early Americans to

\footnotetext{
${ }^{1}$ William Livingston, et al., The Independent Reflector, ed. Milton M. Klein (Cambridge MA: Belknap Press, 1963), 79, hereafter IR.
} 
show off their classical learning, to adopt the literary style of educated elites elsewhere - perhaps in an attempt to demonstrate that they were up to European Enlightenment snuff_-and to draw on history to ideologically bolster their republican case that fighting for independence from Great Britain was a just cause. ${ }^{2}$

How was this imagery deployed at the local level? For insight, we turn to New Jersey's Liberty Hall in Elizabeth Town (to use its first name). The transplanted South Carolinian John Kean (1755-1795), first cashier of the Bank of the United States, married into a prominent regional family led by William Livingston (1723-1790), first governor of the state of New Jersey. Livingston built Liberty Hall as a country estate to escape his law practice across the Hudson River in New York City. He and his family moved there permanently in 1773. Keans and Livingstons lived at Liberty Hall nearly continuously since then until 1995-and never threw anything away. ${ }^{3}$ The archives have only recently been catalogued and made more available. Employing them and other resources, a micro-study of how the Kean paterfamilias and the builder of Liberty Hall used examples from ancient and medieval history provides insight into how people of one time period of history_eighteenth-century South Carolina, New York,

\footnotetext{
${ }^{2}$ See, for instance, Meyer Reinhold, ed., The Classick Pages: Classical Reading of Eighteenth-Century Americans (University Park PA: The Pennsylvania State University Press, 1975); Wolfgang Haase and Meyer Reinhold, eds., Classical Tradition and the Americas, vol. 1, European Images of the Americas and the Classical Tradition, Part 1 (Berlin: Walter de Gruyter, 1994), especially xiv-xix for a survey of literature; Carl J. Richard, The Founders and the Classics. Greece, Rome, and the American Enlightenment (Cambridge: Harvard University Press, 1994); The Golden Age of the Classics in America. Greece, Rome, and the Antebellum United States (Cambridge: Harvard University Press, 2009); and Greeks and Romans Bearing Gifts: How the Ancients Inspired the Founding Fathers (Lanham MD: Rowman \& Littlefield, 2008). Greeks and Romans Bearing Gifts considers the lessons that the founders drew from the past even if those were not always historically accurate. On this point of selective adoption of history, see Evan Shalev, Rome Reborn on Western Shores: Historical Imagination and the Creation of the American Republic (Charlottesville: University of Virginia Press, 2009), which takes a nuanced look at how the founders quite deliberately picked and chose incidents from ancient history as the pre-revolutionary and revolutionary decades progressed. For other approaches to the topic, see Caroline Winterer, The Culture of Classicism: Ancient Greece and Rome in American Intellectual Life, 1780-1910 (Baltimore: The Johns Hopkins University Press, 2002) and The Mirror of Antiquity: American Women and the Classical Tradition, 1750-1900 (Ithaca: Cornell University Press, 2007). A more sweeping treatment, including popular culture, may be found in Margaret Malamud, Ancient Rome and Modern America (Malden MA: Wiley-Blackwell, 2009).

${ }^{3}$ John Kean never lived in Liberty Hall, but his papers are archived there through his marriage to Susan Livingston, William Livingston's niece. After Kean's death, she married Polish count Julian Niemcewicz.
} 
and New Jersey_adopted and adapted prior historical periods. Such a case study reveals how John Kean and William Livingston, with diverse backgrounds and from different parts of colonial and revolutionary America, imagined a new nation by recourse to allusions and lessons from ancient and medieval history. ${ }^{4}$

Europe and America were on fire with the classics in the mid-eighteenth century. This embrace of the past was fueled not only by a traditional and long-standing educational and moral devotion to Greco-Roman languages, literature, and values, but also by the discovery of Pompeii's ruins in 1748, which helped develop the rage for neo-classicism in art and architecture. British and American elites were so steeped in ancient history that any GrecoRoman reference would instantly be recognized. When a member of the British Parliament reacted in 1774 to news of the Boston Tea Party to declare that the Americans must be punished, for example, he shouted Carthago delenda est ("Carthage must be destroyed"). All listening knew immediately he was invoking Cato the Elder calling for Rome to beat back the Carthaginians in the Punic Wars. When the British authors John Trenchard and Thomas Gordon chose Cato as their mouthpiece in their well-known Cato's Letters, which collected 144 essays published in London 1720-1723, they adopted Cato the Younger (ca. 95-46 BCE), the Elder's great-grandson, who was part of the late Roman Republic resistance to Julius Caesar. Cato the Younger committed suicide rather than submit to Caesar; his colleagues eventually lost to Octavian's creation of an empire under his title Augustus. His story was told by Joseph Addison in Cato, A Tragedy, his 1712 play that was later very popular and inspired Americans throughout their struggle with Great Britain. Cato the Younger's voice made Trenchard and Gordon's points

\footnotetext{
${ }^{4}$ I am grateful to Ken Summers, Erin Alghandoor, Bill Schroh, and Terry Golway for access to, scans from, and advice about the Liberty Hall Archive affiliated with Kean University in Union NJ, hereafter LHA. I am especially indebted to Mark Lender, Elizabeth Hyde, Jonathan Mercantini, and this journal's two anonymous peer reviewers for offering valuable advice on earlier versions of this article.
} 
as they followed John Locke on the need for liberty, natural law, and basic human freedoms to trump tyranny. ${ }^{5}$

Eighteenth-century Americans also employed Greco-Roman pseudonyms to combine Latin style with American ingenuity, as in Samuel Adams' Clericus Americanus or Christopher Gadsden's Americus Britannicus in 1769, as well as to protect their identities, particularly when offering words that were seditious and revolutionary. Women participated in the genre, too; most notably, Abigail Adams signed letters with Portia, the admired daughter of Cato the Younger and wife of Brutus, who led Julius Caesar's assassination. Alexander Hamilton chose Publius, maybe the most recognizable example of a Greco-Roman pseudonym, for his Federalist Papers. The real Publius had helped overthrow Tarquin the Proud and establish the Roman Republic along with Lucius Brutus in the sixth century BCE. Hamilton also used Tully, a common shorthand for Marcus Tullius Cicero, when writing against the Whiskey Rebellion; Cicero had spoken out against Catiline and the populist first-century BCE conspiracy he'd led. Cicero would have appealed to Hamilton, given his well-known distrust of the power of the masses. But the AntiFederalists also used classical names: Cato, Brutus, Cassius, and the generic Plebian argued against the Constitution as monarchist and oligarchic. ${ }^{6}$

Where specifically did the founders pick up their references? The short answer is from tutors (for those whose parents could afford them), and America's first grammar schools and

\footnotetext{
${ }^{5}$ Chad Reid, “'Widely Ready by American Patriots': The New-York Weekly Journal and the Influence of Cato's Letters on Colonial America," in Periodical Literature in Eighteenth-Century America, eds. Mark L. Kamrath and Sharon M. Harris (Knoxville: The University of Tennessee Press, 2005), 109-42; Bernard Bailyn, The Origins of American Politics (New York: Vintage Books, 1967), 40-45.

${ }^{6}$ Richard, The Founders and the Classics, 39-42, 123-68. On pseudonyms, see also Charles E. Clark, "Early American Journalism: News and Opinion in the Popular Press," in A History of the Book in America, vol. 1, The Colonial Book in the Atlantic World, eds. Hugh Amory and David D. Hall (Chapel Hill: University of North Carolina Press, 2007), 350. As a teenager, Abigail Adams adopted Diana, goddess of the hunt, while her friends took up other Greco-Roman names. They used Lysander, a Spartan, for John Adams. As an adult, Abigail and John Adams favored Portia for her: Lynn Withey, Dearest Friend: A Life of Abigail Adams (New York: The Free Press, 1981), 12, 15, 62-63.
} 
colleges. In both settings, reading and writing Greek and Latin was the standard prerequisite for a path to prestige. What better way to learn these languages than to read their best practitioners, who could at the same time provide models from history of virtue and vice? John Witherspoon, long-time president of the College of New Jersey (now called and located in Princeton but originally sitting in Elizabeth Town 1746-1747 and then Newark 1747-1756), stated at the beginning of his term, "The remains of the ancients are the standard of taste." In a letter to his son, Witherspoon advised, "A man is not, even at this time, called or considered a scholar unless he is acquainted in some degree with the ancient languages, particularly the Greek and Latin." Such an education was required "to fit young men for serving their country in public stations." Serve the earliest United States they did: according to one tally, during Witherspoon's presidency of 1768-1792, we find studying at Princeton ten future cabinet officers, nearly 40 congressmen, 21 senators, a dozen governors, three Supreme Court justices, and many state officials. The classics were also an opportunity for social mobility: when a young John Adams told his father that he no longer wanted to study Latin, his father told him to dig a ditch instead. After two days, the boy John was back to conjugating verbs. ${ }^{7}$ Closer to the story of William Livingston is Yale College, which he attended. Like Harvard and the other first American colleges, Yale's entrance exam sought to discover if the applicant was "duly prepared and expert in Latin and Greek authors, both poetic and oratorical, as also making Good Latin [sic]."8

Additional evidence of these Greco-Roman classics appears in a fair number of eighteenth-century libraries, featuring especially Tacitus and Cato, and to a lesser extent Plutarch. Their names appear in library lists at Yale, the College of New Jersey, and other public

\footnotetext{
${ }^{7}$ Richard, The Founders and the Classics, 18-20, 30; see also Reinhold, The Classick Pages, 3-6.

${ }^{8}$ William J. Ziobro, "Classical Education in Colonial America," in Classical Antiquity and the Politics of America. From George Washington to George W. Bush, ed. Michael Meckler (Waco TX: Baylor University Press, 2006 ), 17. On "classical learning as an unambiguous marker of elite status," especially in New England schools, see David S. Shields, "Eighteenth-Century Literary Culture," in The Colonial Book in the Atlantic World, 450.
} 
schools and libraries, including Burlington New Jersey's Library Company and several Philadelphia collections. Perhaps John Kean had access to Cato, Sallust, and Tacitus in the Charlestown Library Society, as these volumes were there according to a 1750 catalogue. Private libraries featured these volumes, also, as inventories, catalogues, and auction lists indicate. John Adams, clearly moved by his boyhood aversion to ditch digging, had in his library Caesar, two sets of Tacitus, Sallust, and much of Plutarch, according to a 1790 list. ${ }^{9}$ The Cato mentioned in these lists was likely not the ancient man himself but Trenchard and Gordon's Cato's Letters, which gives us a further example of how the pseudonym was used over the decades since the collection appeared starting in 1720. Cato's Letters are recognized as so influential that, at the National Constitution Center in Philadelphia today, they sit on a shelf in a kiosk devoted to what the founders read, along with Locke, Machiavelli, and other important writings of ancient, medieval, and early modern political philosophy. ${ }^{10}$

\section{John Kean}

The papers of John Kean in Liberty Hall display a variety of references to ancient Greece and Rome, as we might expect, but there are also a fair number of references to medieval and even early modern constitutional developments in England. Some are simply off-hand digressions or allusions — teasing, even — while others are more serious. Kean invokes the specter of Caesar to make his point about tyranny, for instance, but it cannot be denied that this champion of liberty (like others of his era) was involved in the buying, selling, and owning of

\footnotetext{
${ }^{9}$ H. Trevor Colbourn, The Lamp of Experience: Whig History and the Intellectual Origins of the American Revolution (Chapel Hill: University of North Carolina Press for the Institute of Early American History and Culture at Williamsburg VA, 1965), 202-32; Reinhold, The Classick Pages, 6-8.

${ }^{10}$ The National Constitution Center mounted an exhibit on an aspect of our topic, "Ancient Rome and America," in 2010.
} 
slaves, some with Greco-Roman names. Among his Liberty Hall papers are documents identifying a number of slaves by name, among them two called Caesar and Cato. ${ }^{11}$

First, we note some casual Greco-Roman illustrations. In a courtship letter to Susan Livingston (William's niece) before they were married in 1786, Kean sent a lock of his "tresses of nut brown hair" and noted that "among the ancients the hair was held sacred—an offering of it was supposed to be the greatest that could be made to their deities." By way of example, he mentions Achilles offering a lock of his "curling golden tresses" so his beloved friend Patroclus might return safely from the siege of Troy. When he did not, Achilles left the hair on Patroclus' tomb instead. Kean then quotes from Alexander Pope's 1715-1720 translation of Homer's Iliad, book XXIII (skipping a few lines here and there):

O'er the corpse their scattered locks they throw; $[\ldots]$

But great Achilles stands apart in prayer,

And from his head divides the yellow hair;

Those curling locks which from his youth he vow'd

And sacred grew, to Sperchius honor'd flood [...]

Thus o'er Patroclus while the hero pray'd,

On his cold hand the sacred lock he laid. ${ }^{12}$

He then recalls Orestes, who "supplicated the gods to forward his intentions of destroying Egysthus the murderer of Agamemnon, by offering his tresses at the tomb of his father_.."13

\footnotetext{
${ }^{11}$ LHA, John Kean Papers, Historic Indenture and Legal Documents, 1778=03-01-NP-Slavery-J F Grimke=JK1755 for Slaves 0101 and 1778=01-01-NP-Slavery-Jane Grove JK 1755=J F Grimke 0101. On the Keans as slaveholders, see Jonathan Mercantini, "John and Susan Kean and the Culture of Slavery in the New Nation," New Jersey History 127 (2012).

${ }^{12}$ LHA, John Kean Papers, Letters, John Kean to Susan Livingston, \#55, 178x, pp. 2-3. Sperchius is a river in Thessaly. William Livingston also refers to Pope's translation, as we shall see below, in his Philosophic Solitude (1747).

${ }^{13}$ LHA, John Kean Papers, Letters, John Kean to Susan Livingston, \#55, 178x, p. 3. The reference is to Aegisthus, who was the lover of Clytemnestra while her husband Agamemnon fought the Trojan War. When Agamemnon
} 
In a slightly bawdy turn on December 22, 1787, Kean curses Neptune for apparently flooding some trees that Susan, now his wife, had sent him. "Now was I of a poetical turn," he writes, he would give Greek names to the trees. He compares the action of the "watery god" to the rape or ravishing of two nymphs and makes reference to Pluto's rape or kidnapping of Persephone to the underworld, thinking perhaps that he should put in statues of nereids (sea nymphs), sea horses, and tritons. But then he steps back: "but to ravish two nymphs would be too much even for a god and Neptune is among the least lascivious of the heathen deitys [sic] — for he is only charged with one absolute rape which was poor Amphitrite-enough of this in all conscience."14

Ancient times seem to have been on his mind that week: another example comes three days later, from Christmas 1787. Writing once more to Susan, John Kean refers in terms that would strike modern sensibilities as uncharitable or even bigoted about the Roman feast of Saturnalia:

at which time they granted the liberty of doing as they pleased for one day to their slaves--we more indulgent[ly] grant three to ours $\&$ from the $25^{\text {th }}$ to the $28^{\text {th }}$ of December is a continuous scene of every species of debauchery among the lower class of whites and all the blacks in this country-many of whom pay their lives as the price of their intemperance-there are among them some more rational, who enjoy the moments allotted to them by their masters with more propriety-dancing-singing \& plays of

returned, Clytemnestra and Aegisthus plotted to kill him. Years later, Orestes killed his mother and Aegisthus. The stories appear in Homer's Odyssey and in plays by Sophocles, Euripides, and Aeschylus, among other places in Greek mythology and later retellings.

${ }^{14}$ LHA, John Kean Papers, Letters, John Kean to Susan Livingston Kean, 22 December 1787, pp. 3-4. In various Greco-Roman myths, Amphitrite is the wife or lover of Neptune or Poseidon, or simply a personification of the sea, as in her Roman name of Salacia (salty or saltwater). 
various kinds, after the African manner fill up the time \& then they sink again into their wretched state of servitude—-from which God preserves us and ours— ${ }^{15}$

Writing on government, however, is where Kean employed more direct and serious uses of ancient, medieval, and early modern history to make political as opposed to simply stylistic points. In an undated sheaf of papers labeled "Booklet Containing Thoughts on Government," on a page under the heading "Republic," Kean muses, "The republican form of government implies a country the limits of which are sufficiently confined to admit of a speedy and easy communication of the wishes of the people." He then offers some ancient examples of small, confined countries known for their ability to keep safe because they were self-sufficient. Yet he faults the very isolation of which they were proud: "Whatever may be said in praise of the Spartans, the Egyptians, and other distinct nations, who have owed their superior strength, grandeur and permanency to the state of seperation [sic] in which they kept themselves, mankind has received no benefit from these solitary institutions. On the contrary, the spirit of intercourse is useful to all nations, as it promotes mutual communication of their directions and knowledge." He clearly has business on his mind since the next page, headed "Commerce," also looked to historical examples of societies that interacted with a favorable balance of trade for mutual benefit: "By promoting an intercourse with various nations, enlightens, civilizes, $\&$ divests of all prejudices - Great Britain in the $15^{\text {th }}$ century exported her wool to be manufactured-by a prohibitory law she brought her own people to manufacture for themselves." Showing that he had read widely on this point, Kean then added, "The Arabians in the time of Mahomet understood commerce better than any other people. Raynal 2d pa $44 . " 16$

\footnotetext{
${ }^{15}$ LHA, John Kean Papers, Letters, John Kean to Susan Livingston Kean, 25 December 1787, p. 1.

${ }^{16}$ LHA, John Kean Papers, Drafts and Notes, Series 2, Box 3, Folder 32: "Booklet Containing Thoughts on Government." His source seems to have been Guillaume Thomas Francois Raynal, Histoire philosophique et politique des établissemens et du commerce des Européens dans les deux indes (Geneva : J.-L. Pellet, 1782).
} 
In another undated sheaf of musings to be pursued at a later time - they are in pencil and some lines are just a word or phrase - appear "the powers of Caesar," "James 2d," "no election for many years," and "the vulgarity of Cromwell." On the right side of this page, he jotted, "To prove more fully my detest of Kings, I shall draw a picture of the executive that I approve compared with the difference between it and the Kingly power." On the reverse of this page of notes, Kean listed: "Romans, What are the consequences, The Consuls and Dictators." It appears that Kean did, indeed, draw this picture in a speech urging South Carolina's ratification of the Constitution. ${ }^{17}$

We also discover this joining of ancient and medieval ideas in yet another maddeningly undated document. There Kean wrote a few lines about civil liberties: "The only security for the rights of civil liberty is the spirit and habits of the people. In a government where all the powers arise either mediately or immediately from the people declarations of rights become nugatory. The great $\mathrm{C}$ received above 30 confirmations from John to Edw[ard] I in 1297 when it was finally established." The "great C" here is Magna Carta, first signed in 1215 and then, under Edward I in 1297, confirmed in Parliament with the Confirmatio Cartarum after decades of struggles to keep the original provisions intact. Kean indicates with "Hume II-294" that his source is David Hume's The History of England from the Invasion of Julius Caesar to the Abdication of James the Second, 1688, published 1754-1762. Kean's mind was clearly on the Middle Ages though he began a page here, "In ancient times..." and noted that there was no incentive for men to gather in legislative assemblies since they were not paid and received no honor; it was a burden and not worth the trouble or cost. What they wanted were assurances of safety from arbitrary power, he wrote, while the sovereign wanted support, not independent

\footnotetext{
${ }^{17}$ LHA, John Kean Papers, Drafts and Notes, Series 2, Box 3, Folder 21, pp. 1-2. Jonathan Mercantini discovered this speech in LHA, John Kean Papers, Drafts and Notes, Series 2, Box 3, Folder 27, "I have raised in my mind a standard government," pp. 1-4; I am grateful to him for making this connection.
} 
minds, and desired the "consent and concurrence, but this only respects the Barons and gentry." He then quoted almost verbatim a passage from Hume without noting that author as he did on the prior page:

Though the house of commons derived its existence from so precarious \& even so invidious an origin as Leicester['s] usurpation it soon proved when summoned by the legal princes, one of the most useful $\&$ in process of time one of the most powerful members of the national constitution \& gradually rescued the kingdom from aristocratical as well as from regal tyranny. ${ }^{18}$

Kean drew further on medieval precedents in another sheaf labeled "Declaration of Rights" that spends most of its time demonstrating how, bit by bit in the seventeenth century, England moved from Tudor-Stuart monarchy to the Glorious Revolution of 1688, surely following Hume once more. This sheaf dates perhaps from early 1788, which was the centennial of the Glorious Revolution as well as the time of the ratification debates about the proposed U.S. Constitution. The first or last page (it is unclear in the record) contains some more revealing medieval notes to himself: "M. Charta 1214 John Leicester calling in the commons 1258 to serve his own particular ends. Henry 3 son of John Establish[ment] of H[ouse] of C[ommons] firmly 1295 Edward I son of Henry 3d." Ironically, right next to these notes concerning medieval steps toward popular sovereignty appears what must be an inventory of his slaves. Under "Hilton Head January $88, "$ he listed:

105 Negroes

5 Beaufort

1 St. Helena

5 Neck

\footnotetext{
${ }^{18}$ LHA, John Kean Papers, Drafts and Notes, Series 2, Box 4, Folder 4, “In Ancient Times,” pp. 1-2.
} 


\section{Total}

\section{Charleston}

\section{New York ${ }^{19}$}

We find Kean returning to the seventeenth century in another undated sheaf where, after a discussion of natural and civil liberties, we find these English steps toward the kind of government he sought: "Petition of rights granted 1628, Charles beheaded 1649, Habeas corpus granted 1679 Charles II, James 2d abdicated \& the Bill of Rights stipulated with William prince of Orange 1688 - a struggle thro 4 Reigns \& during a term of 85 years \& but an imperfect safety obtained at last." Moving backwards in time to the Middle Ages on the next page: "Norman Conquest 1066, Great Charter granted by John 1214, democratic branch introduced into the government of England 1258 — by Simon De Mountfort [sic] Earl of Leicester and the Barons in opposition to the King (Henry 2d [actually Henry III]) and for their own private aggrandisement - These represent[ations?] discontinued until the reign of Edward the $1^{\text {st }}$ when they were more fully confirmed \& began to have due weight in government in the $23 \mathrm{~d}$ year of Edward $1^{\text {st }}$ in the year 1295."20

To what medieval and early modern developments was he referring? The Magna Carta, of course, is the foundational document of participatory constitutionalism in the west, although Kean consistently placed it incorrectly in 1214, a year before it was signed. "Leicester's usurpation" refers to the actions of Simon de Montfort (ca. 1208-1265), sometimes called the founder of Parliament and whose title was Earl of Leicester. De Montfort solidified opposition to

\footnotetext{
${ }^{19}$ LHA, John Kean Papers, Drafts and Notes, Series 2, Box 3, Folder 14, "Declaration of Rights," pp. 1-4.

${ }^{20}$ LHA, John Kean Papers, Drafts and Notes, Series 2, Box 3, Folder 29, pp. 1-3. In another undated sheet, this in pencil, we find Kean mentioning a list of complaints by the commoners under Edward III of the monarchy impinging on their rights of consent: LHA, John Kean Papers, Drafts and Notes, Series 2, Box 4, folder 5 - on the reverse of which is a list of measurements for window shutters and a chimney.
} 
England's King Henry III (not Henry II, Kean's mistake here) with the Provisions of Oxford in 1258 and Provisions of Westminster in 1259, which pressed the king to share power by consulting barons regularly — in fact, by making decisions with them instead of simply seeking their assent or counsel—and by meeting in parliament three times a year with a larger body of representatives chosen by the barons themselves. The king, in turn, was promised taxes, but the barons would exercise oversight of the royal treasury and the application of justice. The Provisions were quite a success: eight parliaments sat between 1258 and 1261. While these are still barons - a House of Lords, in embryonic form - the commoners would soon have their due. In 1265, de Montfort, acting nearly as king himself, called for towns and country shires to send representatives of their own choosing to Parliament for the first time. These town burgesses and rural knights came bearing documents giving them actual delegated power to deliberate and to decide, as well as to bind the communities they represented. The year 1295 refers to the so-called Model Parliament, which is a bit overblown a title but indeed drew elected representatives armed with the authority to conclude business and not just give assent. We cannot find a cleanlydelineated House of Lords and Commons in 1295, but the elements are there in a pair of knights and burgesses from each shire and town with full power to make decisions, particularly related to taxation, which is a step toward the power of the purse. So while John Kean may have gotten a few details wrong, the tale he told of a creeping constitutionalism in English history from the important thirteenth century into the decisive seventeenth century's Glorious Revolution was spot-on, as his British foes might begrudgingly put it.

\section{William Livingston}

William Livingston studied at Yale where the classics were a curricular staple. It is undoubtedly one of the places where he became steeped in classical literature and history, though 
it must be remembered that the teenager who sought entrance to Yale already needed a good grounding in Greek and Latin. We find him drawing on this training as early as 1747 . In his Philosophic Solitude: or, The Choice of a Rural Life, the 24-year-old is somewhat precociously envisioning a life of leisure and meditation even as he studied law in New York City. ${ }^{21}$ Written by "a Gentleman educated at Yale College," the poem begins with two prefaces, likely but not certainly written by Livingston himself. The first, signed N.W., mentions classical places and names like Arcadia, Saturn, Phoebus (a reference to Apollo and/or the sun), and "the Trojan hero" (presumably Hector). ${ }^{22}$ The second preface is addressed to "Mr. L*********" and signed W.P.S. As with John Kean's work, there is a reference to Alexander Pope and Homer, here with praise:

In thy harmonious verse united shine

Pope's nervous phrase, and Homer's sacred fire...

W.P.S. later notes that the author drew on the ancient history of Rome and Britain to make his points:

To raise the genius, and exalt the thought,

What the learn'd focus of Rome and Albion wrote,

You travel o'er, --- and taught by heav'n you sing

Each author's merit on the founding string. ${ }^{23}$

Livingston's text has recourse to many casual and quick references to Aurora (goddess of the dawn), the Elysian fields, Socrates' wife Xanthippe, Horace, Orpheus, "seers of old,"

\footnotetext{
${ }^{21}$ American Antiquarian Society, item 5986. It was first published by James Parker in 1747 in New York and enjoyed several reprintings during the next few decades. For an analysis seeking what this essay reveals about the young Livingston's political vision, particularly concerning the link between private and public virtue, see Frank Shuffleton, "'Philosophic Solitude' and the Pastoral Politics of William Livingston," Early American Literature 17 (1982): 43-53.

${ }^{22}$ Philosophic Solitude, pp. iii-vi.

${ }^{23}$ Philosophic Solitude, pp. vii-viii.
} 
goddesses and gods, Jove, Venus, Phoebus, the muses, Titans, Virgil's Aeneas, King Priam with prince Paris and his lover Helen whose romance started the Trojan War, Neptune, Rome's vestal virgins tending the city's sacred fire, and Juno. ${ }^{24}$ Once, Livingston adopted a famous phrase from Homer- "rosey-finger'd morning dawn" 25 _ and then there are a few references favorably comparing unnamed friends identified by first letters only with ancient models. So in discussing the fact that his rural retreat would not be solitary but shared with like-minded souls, surely in the style of ancient villas of retreat, he praises $\mathrm{W}^{* * * *}$, a friend from Yale, and dear $\mathrm{A} * * * *$, for demonstrating the eloquence of Roman senators:

Before the roman bar, while Rome was free,

Nor bow'd to Caesar's throne the servile knee,

Immortal Tully [Cicero] plead the patriot cause,

While ev'ry tongue resounded his applause. ${ }^{26}$

Elsewhere he provides his reading list:

These for Delight; -- for Profit I wou'd read

The laboured volumes of the learned dead.....

Th' unconquerable Sage [identified as Cato] whom vertue fir'd

And from the tyrant's lawless rage retir'd,

When victor Caesar freed unhappy Rome

From Pompey's chains, to substitute his own.

Longinus, Livy, fam'd Thucydides,

Quintilian, Plato, and Demosthenes,

Persuasive Tully [Cicero], and Corduba's Sage [identified as Seneca],

${ }^{24}$ Philosophic Solitude, pp. 14, 15, 17, 19, 27, 31, 33-35, 38, 40-41.

${ }^{25}$ Philosophic Solitude, p. 20.

${ }^{26}$ Philosophic Solitude, pp. 17-19. 
Who fell by Nero's unrelenting rage;

Him [identified as Socrates] whom ungrateful Athens doom'd to bleed,

Despis'd when living, and deplor'd when dead. ${ }^{27}$

Since Livingston mentioned reading lists, it is instructive to find two handwritten documents in the Massachusetts Historical Society gathered together and affiliated with him. One looks like a wish list of what a good library should hold or pages of notes jotted down by someone taking an inventory, presumably of Livingston's shelves, perhaps even at Liberty Hall. They are followed by a stitched sheaf that appears to be an inventory and financial appraisal of Livingston's books at his death. ${ }^{28}$ While we cannot say surely which books he acquired, let alone read, and precisely when, they do indicate his influences.

These two lists mention many well-known and standard Greco-Roman classics along with works of poetry and politics. The wish list or notes for an inventory indicate that he held or wished to have particular works and authors related to the classics: Josephus' Antiquities, Pliny, Tully (Cicero), Roman histories (including Tacitus, Livy, and Dio Cassius), Plato, Marcus Aurelius, Aristotle, Longinus, Quintilian, Virgil, Seneca, Pythagoras, Plutarch, and Epictetus. He notes at one point "and of these it may be worth while to have in a public library, all the political works of some of them, and only some particular works of the rest," which hints that this is, indeed, a wish list and not just one for private consumption. The second list, the inventory and appraisal with monetary notations, is alphabetical and mentions among many other items Augustine, a Bible, Julius Caesar's commentaries, a number of works by Cicero (especially orations), a classical dictionary, Diodorus Siculus, a history of Greece, the Imitation of Christ (typically attributed to Thomas à Kempis), Justin, Justinian's codex, Juvenal's satires in English

\footnotetext{
${ }^{27}$ Philosophic Solitude, pp. 36-37.

${ }^{28} \mathrm{I}$ am indebted to Elizabeth Hyde for providing a photocopy of these documents (Massachusetts Historical Society Ms. N-1579.1) and for sharing her insights.
} 
and Latin, Livy in six volumes, a New Testament, Pliny in Latin, Tacitus in Latin, Theodosius in French, Virgil's Georgics in French, and Virgil's Eneid [sic] in Latin.

So we have a good sense of what Livingston owned, read, or wanted to own and read when it came to the classics. We have seen some rudimentary allusions in the hand of the young man in Philosophic Solitude, but what happened to this Greco-Roman influence as Livingston matured and came into his own career? We will pursue this question by looking closely at his writings at two stages in his career: as the emerging player through his essays in The Independent Reflector in the early 1750s, and then as a major political influence and governor in the NewJersey Gazette and some letters in the 1770s-1780s.

The Independent Reflector is comprised of 54 pseudonymous essays published in 1752 and 1753. Although few handwritten manuscripts survive, the essays' modern editor Milton Klein has determined that Livingston wrote 33 (often signed as Z.), co-wrote four and maybe a fifth, and was solely responsible for ten more (if Livingston is also B., as Klein believes). ${ }^{29}$ No less an authority than Bernard Bailyn detected the unmistakable British influence of Trenchard and Gordon's Cato's Letters from several decades earlier on The Independent Reflector. ${ }^{30}$ One of the major themes of these essays is the resistance to establishing in New York City a college under the Church of England's control that was also supported by public funds. This battle was lost with the establishment of King's College, later Columbia University; nevertheless, the essays still demonstrate not only Livingston's insights into a key church-state issue, but his continuing adoption of Greco-Roman style and examples to make his points.

We will concentrate on three observations: his use of Latin, his focus on virtue, and his recourse to historical examples of bad decisions and actions meant to inform current decision-

\footnotetext{
${ }^{29}$ IR, 446-49.

${ }^{30}$ Bernard Bailyn, The Ideological Origins of the American Revolution (Cambridge MA: Belknap Press, 1967), 3637 n.19; see also Klein, IR, 21-28, 450-52.
} 
making. First, though the use of Latin is a stylistic issue, it is illustrative of who Livingston was trying to reach. Number 9, on January 25, 1753, began with Latin epigrams from Sallust (86-34 $\mathrm{BCE})$ and Horace (65-8 BCE), two authors of the late Roman republic fighting a rear-guard action against tyranny and the loss of personal virtue.

Omnia venalia Romae [Everything can be bought in Rome] Sallust

O cives, cives, querenda Pecunia primum est,

Virtus post nummos,---

[O citizen, citizen, in seeking Money first,

Virtue comes to nothing,---] Horace

The essay concluded with a Latin line from one Juvenal's satires from the late first/early second century CE.

Ille crucem, pretium sceleris tulit, hic diadema.

[One bears the cross, another a crown for doing the same crime.] ${ }^{31}$

Curiously, at this point there follows directly a letter signed by "Ralph Syntax" questioning the use of Latin though not the advice contained in the ancient words: "It is, in short, the Language in which they are delivered, and not the Sense of the Mottos, which has given the Umbrage; and that for no less substantial a Reason, than because many of your Betters are unprovided with Dictionaries." Was this a genuine letter to the editor or perhaps a gentle nudge from the printer or a co-author-or even a self-referential scold to Livingston by Livingston? We do not know, but Milton Klein's delightful footnote is worth quoting in full here: "While Livingston could appreciate the reaction to his Latinisms, he did not let up immediately. The first nine issues [of The Independent Reflector] had contained some sixteen; the next ten included twenty, but

\footnotetext{
${ }^{31} I R, 111,116$, my translations.
} 
thereafter the number tapered off." 32 Two months later, in no. 17 from March 22, 1753, for example, Livingston quoted in Latin from Cicero and Horace, but added an English translation after Horace's Latin. He quoted Quintilian, once in English and once in Latin, and Virgil in Latin. It seems that, over time, Livingston got Ralph Syntax's point: to reach a broader audience, perhaps he did not need to wear his learning quite so heavily on his sleeve. ${ }^{33}$

The second point is Livingston's use of classical material to offer examples of the kinds of virtue that should be cultivated in young people in order to serve the state well. This theme of private virtue for public service is a major element of these essays and a familiar aspect of Greco-Roman literature on statesmanship. In one, Livingston declared that the Romans in the time of the Republic encouraged merit and preferred public virtue that led to public honor as opposed to the corrupt and corrupting Roman Empire that followed, where public office was often for sale. Moving backwards in time, he then offered as models the Athenians and Spartans who

...conferred the Honours of the State, according to the real Worth of the Candidates. In those celebrated Common-Wealths, Men rose to the first Rank, by the Strength of their Genius, and their personal Valour. This naturally gave Rise to a numerous Race of Heroes, and produced a Multitude of Philosophers, Statesmen, Poets and Orators: And yet so great was the public Frugality, as to enable them to leave no Merit unrewarded. A Twig of Laurel was as illustrious a Distinction as a splendid Pension. ${ }^{34}$

There is a clear overstatement and idealization of the comparison in retrospect, of course, but still even as early as 1753, Livingston hoped for a virtuous republic in the face of a corrupting

\footnotetext{
${ }^{32}$ IR, 117 n.5.

${ }^{33} I R, 171-77$.

${ }^{34} I R, 113-14$.
} 
empire. This contrast will become an important part of the American revolutionary narrative versus George III and Parliament.

The role of public education in the development of a worthy republic was important to Livingston. On March 22, 1753, he cited Cicero, once more in Latin, to say, "Indeed what greater or better gift could we possibly offer to the republic unless we teach and instruct the young?" The goal of education is to help young men discover how best to use their God-given gifts for public service in a spirit of liberty and loyalty, honor and sacrifice.

Hence the Education of Youth hath been the peculiar Care of all the wise Legislators of Antiquity, who thought it impossible to aggrandize the State, without imbuing the Minds of its Members with Virtue and Knowledge. Nay, so sensible of this fundamental Maxim in Policy, were PLATO, ARISTOTLE, and LYCURGUS, and in short all the ancient Politicians who have delivered their Sentiments on Government, that they make the Education of Youth, the principal and most essential Duty of the Magistrate. ${ }^{35}$

Livingston tied this goal of virtue to his third use of classical references: pointing out bad historical examples to be avoided, which is something ancient historians regularly said was one of the main objectives of studying history. To provide just one example, in the preface to his history of Rome, Livy (59 BCE-17 CE), a Roman historian who lived during the republic's fall and the first decades of the Roman empire, declared: "There is this exceptionally beneficial and fruitful advantage to be derived from the study of the past, that you see, set in the clear light of historical truth, examples of every possible type. From these you may select for yourself and

\footnotetext{
${ }^{35} I R, 171-72$, my translation of Cicero. On this point that a good education produces virtue and not vice for public service, see also $I R, 288$, from July 12, 1753, no. 33 .
} 
your country what to imitate, and also what, as being mischievous in its inception and disastrous in its issues, you are to avoid." 36

Sounding very much like Aristotle who praised the Spartans for taking the best of government by the one, the few, and the many, Livingston in The Independent Reflector on July 12, 1753 related his opinion that, "no more than that a Compound of Monarchy, Aristocracy and Democracy, such as is the English Constitution, is infinitely the best." Within a few lines, he turns to virtue and vice once more. There Livingston begins an extended comparison with good and bad examples drawn from Roman history:

After the Change of Government wrought by the Usurpation of Julius Caesar, the Emperors were, in Fact, vested with absolute Power: And tho' the Commons retained some small Shadow of their pristine Liberty, yet at every Appearance of the Legions, who were entirely under the Command of the Emperor, they were dispersed, like the Shades of Night by the Splendor of the rising Sun. In this Situation, the People were entirely subject to the Will of their Caesars; they had given up to them so much of their original Power, that they had not enough left to secure themselves against Slavery and Oppression. When their Ruler found his Happiness in the Prosperity of his People, they enjoyed the Sweets of Liberty; but no sooner did his Views center in the Pursuit of his own Interest, and the Gratification of his private Passions, than they were reduced to the wretched Condition of Slaves. ${ }^{37}$

\footnotetext{
${ }^{36}$ Livy, History of Rome (New York. E. P. Dutton and Co., 1912), preface, as found on http://www.perseus.tufts.edu/hopper/text?doc=Perseus\%3Atext\%3A1999.02.0026\&redirect=true, accessed 23 July 2012. On the value accorded to the study of history in the colonial period, see Reinhold, The Classick Pages, 16-18. ${ }^{37}$ IR, 288-89. Aristotle praised Sparta's mixed government system in his Politics, 1265b: Aristotle, Aristotle in 23 Volumes, vol. 21, translated by H. Rackham (Cambridge, MA: Harvard University Press, 1944), as found on http://www.perseus.tufts.edu/hopper/text?doc=Perseus\%3Atext\%3A1999.01.0058\%3Abook\%3D2\%3Asection\%3D $\underline{1265 b}$, accessed on 23 July 2012.
} 
Previously, on December 21, 1752, Livingston had painted a picture of eighteenthcentury Italy as a land under the tyrannical grip of a Roman Catholic pope crazed with charging enemies with heresy and burning them. What a change from Republican Rome, he says, whose heroes

are succeeded by cloistered Monks and castrated Musicians, in Subjection to a filthy old Harlot, that pretends to a Power of devouring her Mediator, and claims a right to eat up her People. Let him survey all Italy, once the Seat of Art and Arms, and every Thing great and valuable; now the joyless Theatre of Oppression and Tyranny, Superstition and Ignorance. Let him behold all this; and when he has finished his Survey, then let him believe and tremble. ${ }^{38}$

The irony here is that the pope at the time, Benedict XIV (Prospero Lambertini, who reigned as pope 1740-1758) was quite learned in history. He wrote canonization procedures that lasted more than two centuries and was so open-minded that no less a philosophe than Voltaire dedicated a play to him. In this case, at least, Livingston did not quite apply his history lessons to current events so well.

Now moving forward about 20 years, we find another cache of documents where Livingston turned to Greco-Roman pseudonyms and examples to illustrate his points, this time in his favored publishing outlet, the New-Jersey Gazette, starting in the late 1770 s. ${ }^{39}$ As with his earliest writings and those of John Kean, Livingston sometimes simply sprinkled in references to the classics. In an April 1, 1778 poetic note to George Washington, Livingston mentioned Astrea

\footnotetext{
${ }^{38} I R, 79$. This is the same essay from which this article's opening lines are drawn.

${ }^{39}$ Carl E. Prince, et al, eds., The Papers of William Livingston, 5 vols., 1979-1988. Volumes 1 (January 1774-June 1777) and 2 (July 1777-December 1778) were published in Trenton NJ by the New Jersey Historical Commission. Volumes 3 (January 1979-June 1780), 4 (July 1780-April 1783), and 5 (April 1783-August 1790) were published in New Brunswick NJ by Rutgers University Press for the New Jersey Historical Commission. Subsequent references will appear as Papers followed by volume and page numbers. On the attribution of pseudonymous writings to Livingston despite a lack of autograph manuscripts, see Papers 2:3-6.
} 
(a goddess of justice), the war-god Mars, the Roman god of fruit trees named Pomona, the great Athenian lawgiver Solon, and Rome’s tragic hero Brutus. ${ }^{40}$ In a 1783 letter, Livingston favorably referred to Rome's republican government with a senate and elected consuls; the next year, he praised the Roman tax system (albeit under an emperor) that gave tax breaks to married couples and penalized bachelors. In 1788, writing to Yale's president Ezra Stiles, Livingston referred to "my most favourite of all biographers, Plutarch," whose name did, indeed, appear in his book wish list or inventory notes. ${ }^{41}$ In an August 1782 essay in the New-Jersey Gazette, he signed his name as Caius to oppose British imports, using the example of Alexander the Great's father from the fourth century BCE. Philip of Macedon, Caius wrote, held that "no city was impregnable into which an ass might enter laden with gold," adding, "and it is said he made himself master of more fortified towns by this sort of artillery, than by the strength of his armies." 42

On other occasions, Livingston used pseudonyms like Pluto and Charon playfully. In a letter to himself, for example, Livingston writes as Pluto from "Infernal Regions" in early December 1778 in the Royal Gazette. There, Pluto chastised the governor for worrying while he enjoyed the precarious position of the American forces. "The distress of America commands universal attention," Pluto wrote. "Her inhabitants, particularly in the Jerseys, are considerably indebted to you, for their present accumulated miseries.... [Y] ou will infallibly be doomed to disgrace, perhaps to destruction." As for Livingston's abilities as governor, his alter ego Pluto spared nothing:

\footnotetext{
${ }^{40}$ Papers, 2:277-80.

${ }^{41}$ Papers 5:57, 99, 363.

${ }^{42}$ Papers 4:455-58, with quotation at 455. Caius is sometimes rendered Gaius in Latin sources and likely refers to Gaius Gracchus (ca. 152-121 BCE), a populist whose land and legal reforms sought to put property and political power in the hands of the masses. He rose to the position of tribune of the plebians, roughly the equivalent of the modern-day speaker of the house or parliament in representative governments.
} 
You should be dumb on the science of politics, and avoid comparative descriptions for ever.-You aim at every thing, and perform nothing. Your unruly temper will prevent you from shining at the bar; your want of sagacity and discernment from figuring in the senate, and as to writing, you are still unacquainted with the polish'd diction of a fine writer. Literary merit is by no means your forte...

Pluto's letter is followed by another a few months later in April 1779, in which Pluto offered Livingston the post of "President of the Council in my dominions." 43 Another light-hearted example occurred when Livingston signed himself Trismegistus to chide British voices, such as Lord North's, which urged American reconciliation with England in 1778. Hermes Trismegistus (Hermes Thrice-Great) was a synthesized Egyptian and Greek god of magic, alchemy, and mysticism. Since Trismegistus was a keeper of wisdom who conveyed it to others, perhaps Livingston fancied himself as a sage and prophet in this letter. ${ }^{44}$

Why Livingston chose this or that Latin pseudonym for particular topics will likely never be known for certain, but there are some patterns apart from these stylistic flourishes. Livingston had some favorite pseudonyms, turning for instance to Hortensius when his quill turned caustic. Hortensius demeaned and satirized British officers and officials, including King George III, and even chided rich ladies in Bergen to turn their surplus petticoats into soldiers' uniform pants. More seriously, Livingston employed Hortensius for a lengthy rhetorical reflection on reason and faith in June $1786 .{ }^{45}$ But who precisely he meant by Hortensius is unclear. There are two candidates, neither affiliated with a biting tone. The first is a little-known Roman character attached to an important step in the development of the Roman Republic. In the third century

\footnotetext{
${ }^{43}$ Papers, 2:497-99. This letter is preceded by one to Livingston from Charon, the boatman who ferried dead souls across the river Styx to Hades: Papers 2:496-97. The second Pluto letter, also from the Royal Gazette, is found in Papers 3:59-60.

${ }^{44}$ Papers 2:337-38

${ }^{45}$ Papers 2:137-43, 156-57, 168-69, 191-92, 214-17, 259-63, 323-27, 428-34, 464-66; 5:250-54.
} 
BCE, a Roman named Quintus Hortensius passed the Lex Hortensia, which made laws approved by plebians (roughly non-aristocrats) called plebiscites binding on all Romans, even those above them in the social ladder. The second candidate is another Hortensius, ca. 114-50 BCE, a lawyer who once lost a case to Cicero but ended up as the famous orator's ally. Hortensius held a number of offices, including serving as consul in 69. Cicero wrote a treatise titled Hortensius in his later years, about $45 \mathrm{BCE}$ when his public and private lives were in shambles, but this work is lost except for its name. Enough fragments survive to reconstruct at least its theme and genre: a dialogue among friends in a villa about how important it is to study philosophy. ${ }^{46}$ What is intriguing is that Livingston did not employ Hortensius when talking specifically about government, as might be expected if he used the first Hortensius as his model, although using the second Hortensius for the reflections on faith and reason make sense for the 1786 essay.

Livingston reserved two particular Roman pseudonyms for weightier points: Cato and Scipio appear in a fair number of essays. He signed as Cato, for example, for the more philosophical essays, specifically when discussing virtues. In January 1778, he offered a dozen worthy characteristics of "a good Assembly-Man," among them a desire to help the common good, to work industriously, to follow his conscience, and to act virtuously at all times. That same month, Cato praised education as essential to the republic. Studying was so important that young men in college should be deferred from military service. In February 1778, Cato spoke at length about the importance of common consent to fight tyranny and the need for "liberty of conscience." 47

For more practical matters, especially concerning finances, Scipio was Livingston's favored nom de plume, maybe referring to the champion of the Roman Republic Scipio the Elder

\footnotetext{
${ }^{46}$ For more on this lost treatise and its influence, see John Hammond Taylor, "St. Augustine and the Hortensius of Cicero," Studies in Philology 60 (1963): 487-98.

${ }^{47}$ Papers 2:162-65, 179-80, 203-205, 234-38.
} 
or Africanus, so-called because he defeated the north African general Hannibal at the battle of Zama in the Second Punic War with Carthage in 202 BCE. The other option would be this Scipio's son, Scipio Aemilianus or the Younger, also nicknamed Africanus because of his own sequel success in defeating the Carthaginians, in his case in the Third Punic War that finally ended their threat to Rome in 146 BCE. If the junior Scipio is meant, then Livingston's source could have been Cicero's Dream of Scipio from his De re publica. We find Livingston signing himself as Scipio in two addresses to the New Jersey State Legislature in October and November 1780 as well as in an April 1781 letter concerning cash, credit, and currency issues. ${ }^{48} \mathrm{He}$ also turned to Scipio to lay down good practices for judicial tenure and to encourage people to pay their taxes, but also to denounce rowdy taverns with gambling. ${ }^{49}$

Another example where some clear intent appears is when he chose the name Camillus. On April 29, 1778, Camillus refuted the importance of recent news of British determination and an increased army, warning that Americans were resolved to resist: "After a struggle of three years, the beam on which were suspended the fate of both countries, has at last turned in favour of America.... [R]emember that the blessings of freedom and a state of peace can only be obtained and secured by the union and INDEPENDENCE of our American States. ${ }^{" 50}$ Livingston must have drawn Camillus (ca. 435-365 BCE) from the Parallel Lives of Plutarch, his favorite Roman biographer. Plutarch called Camillus the second founder of Rome, in part because of his role in driving away Gauls invading Roman territory, which perhaps worked as a stand-in for the British occupation in Livingston's eyes. As Quintus Hortensius would do about a century later, Camillus also played a political role in the development of Rome's Republic that would attract

\footnotetext{
${ }^{48}$ Papers 4:76-80, 82-86, 185-86.

${ }^{49}$ Papers 5:101-104, 131-34, 137-41. In a less noble example, Livingston signed himself as Scipio in a bitter exchange with his rival Samuel Tucker. See Papers 5:67-68 for a discussion. For the Scipio attacks on Tucker, see Papers 5: 83-86, 89-90, 91-96, 104-108, 110-19, 122-30, 145-49.

${ }^{50}$ Papers 2: 316-19.
} 
Livingston: although a patrician, Camillus forged ties with plebians and was known for sharing power. $^{51}$

John Kean and William Livingston turned to ancient and medieval history along with classical pseudonyms to adopt and adapt a noble sense of historical duty, context, and service. The writings of these two colonial and then revolutionary gentlemen represent an historical awareness ranging from South Carolina northward through New Jersey and New York up to Connecticut's Yale. Ancient Greece and Rome - and, in John Kean's case, medieval Britainoffered these two important voices the chance to step back from daily details and to place their goals on a broader canvas by invoking the mantle of a glorious past as they helped to form a new nation's future.

Christopher M. Bellitto, Ph.D., is associate professor of history at Kean University, where he teaches ancient and medieval history.

\footnotetext{
${ }^{51}$ Plutarch, The Parallel Lives, trans. Bernadotte Perrin. Loeb Classical Library (Cambridge MA: Harvard University Press, 1914), vol. II, Life of Camillus.
} 